Summer 2007

\title{
Relational Contract and the Nature of Private Ordering: A Comment on Vincent-Jones
}

David Campbell

Durham University

Follow this and additional works at: https://www.repository.law.indiana.edu/ijgls

Part of the Contracts Commons, Government Contracts Commons, and the International Law

\section{Commons}

\section{Recommended Citation}

Campbell, David (2007) "Relational Contract and the Nature of Private Ordering: A Comment on VincentJones," Indiana Journal of Global Legal Studies: Vol. 14 : Iss. 2 , Article 5.

Available at: https://www.repository.law.indiana.edu/ijgls/vol14/iss2/5

This Symposium is brought to you for free and open access by the Law School Journals at Digital Repository @ Maurer Law. It has been accepted for inclusion in Indiana Journal of Global Legal Studies by an authorized editor of Digital Repository @ Maurer Law. For more information, please contact rvaughan@indiana.edu.

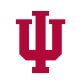

JEROME HALL LAW LIBRARY

INDIANA UNIVERSITY

Maurer School of Law
Bloomington 


\title{
Relational Contract and the Nature of Private Ordering: A Comment on Vincent-Jones
}

\author{
David Campbell
}

\begin{abstract}
This paper focuses on the enormous growth of contract in the public sector over the last twenty years as part of the development of the "new public management." In the United Kingdom, the most penetrating assessment of the significance of this growth for the law of contract, its theory and its use, is Peter Vincent-Jones's The New Public Contracting, the thrust of which has been the basis of Vincent-Jones's contribution to this issue, The New Public Contracting: Public versus Private Ordering? In this paper, the author examines the welfarism of public sector contracting by means of a comment on Vincent-Jones's excellent account of the contractualization of the public sector.
\end{abstract}

\section{INTRODUCTION}

In W.W. Jacobs's excellent short story The Monkey's Paw, a couple comes into possession of an enchanted, mummified monkey's paw that has the power to grant three wishes. They first wish for enough money to allow them to clear the mortgage on their home. They get the money, but it comes to them as compensation for an industrial accident that kills their only surviving child. It is, in fact, what happens with the second and third wishes that makes this a very striking story-indeed elevates it to something like Poe's level. But it is the paradox expressed in the fulfillment of the first wish, which is captured in the anonymous epigram: "Be careful what you wish for, you may receive it," which prefaces some published versions of the story, ${ }^{1}$ that is of interest here.

For I have received a substantial part of what I wished for when I began to form independent opinions about the law of contract some twenty-five years ago,

* Head of Department of Law, Durham University, UK.

1. Though not, it appears, the original. W.W. Jacobs, The Monkey's Paw, Harper's Monrhly MAG., Sept. 1902, at 634. 
and I find that there is much that I do not like. When I formed my views, the "classical law," though clearly in what the modern philosophy of science would call its "degenerating" phase, remained the dominant paradigm of contract law scholarship, and alternatives such as the "relational" theory of contract, to which I personally subscribe, were marginal. ${ }^{2}$ So far as one can say, these alternatives remain marginal to the teaching of students of the law of contract and to the selfunderstanding of practitioners of that law, but they now hold an indisputably important position in the leading scholarship, in the sense that no one competent to contribute to that scholarship would deny the irritating counter-evidence to the classical law to which these alternatives have drawn our attention. Though in the United Kingdom the most academically influential response to the "death" of the classical law has been a reactionary attempt to revive its formal method in new guises, notably a general law of obligations based on unjust enrichment or restitution, at least the death has been recognized, and the executioner role played by the relational theory acknowledged by the more widely learned contributors. ${ }^{3}$ In this sense, as even the leading critics of the relational theory now acknowledge: "To a significant degree, we are all 'relationalists' now."

Leaving aside the significance of legislation, the counter-evidence to the classical law has emerged in those cases that cannot be reconciled with Langdellian formalism's core conception of contracts as the agreements of atomistic individuals, in which the function of the law is to give effect to the parties' intentions as (it was maintained) literally expressed in those agreements. Though a background social dimension of, to use von Mises' term, the "maintenance of peace"s has always been recognized as necessary, the essence of the classical model is to depict an amoral sphere of unconstrained bargaining motivated by individualist utility maximization: laissez faire. This is now widely recognized not to be good enough, for we are moving toward a general understanding that the law of contract articulates a social dimension that is at the heart of contract. Even the simplest contract is not a relationship between two parties, but is their relationship mediated through a third

2. My own principal contribution to the analysis of the "death of contract" is David Campbell, The Undeath of Contract: A Study in the Degeneration of a Research Programme, 22 Hong Kong L.J. 20 (1992).

3. See, e.g., Ewan McKendrick, The Regulation of Long-term Contracts in English Law, in GooD Faith and Fault in Contract Law 305 (Jack Beatson \& Daniel Friedmann eds., 1995).

4. Randy E. Barnett, Conflicting Visions: A Critique of Ian Macneil's Relational Theory of Contract, 78 VA. L. Rev. 1175, 1200 (1992).

5. Ludwig von Mises, Socialism: An Economic and Sociological Analysis 36 (J. Kahane trans., Liberty Classics 1981) (1932). 
party, the state, which gives effect only to socially understood and politically endorsed intentions. The free market expression of the choices of individuals is, at its heart, a social institution.

An increasing consciousness of the tripartite, rather than binary, social structure of the law of contract is being developed through extensive criticism of the core doctrines of the classical law. We now acknowledge that acceptance cannot be accommodated within the classical offer and acceptance model, that enforceability cannot be a matter of the classical sufficiency of consideration and an untrammeled respect for sanctity, that interpretation cannot be a matter merely of grasping the "natural and ordinary meaning of the words used," and that remedies cannot be a matter of literally enforcing the promises of defendants. In general, the claim that the purpose of contract law is to give effect to the intentions of the parties has had to be relinquished under the pressure of recognizing that the crucial, implicit dimensions of those intentions make this claim the statement, not the solution, of the problem of determining what those intentions are in the view of the reasonable third party institutionalized in the state. ${ }^{7}$ The purpose of the law of contract currently is better stated as that of "fulfilling reasonable expectations."

To the extent that these developments represent a more adequate understanding of the social dimension of economic exchange, and therefore allow the more adequate fashioning of the legal institution of contractual promising to support such exchange, they are most welcome. It is in this sense that I have received what I wished for, for I have argued for the relational theory of contract as an adequate understanding of the social dimension of contract. But $I$, for one, did not want to see one important result of this greater attention to the social dimension of contract, which has been the development of an unattractive "welfarist" law of contract that has not stopped at the eradication of the atomistic individual but has moved on to the erosion of the positive individual dimension of contract expressed in choice under freedom of contract. If, in watered down forms, the classical law, and reactionary attempts to revive it after its death, still dominate the subject, I fear this is so in part because the welfarist critique of the classical law does not

6. Investors Compensation Scheme Ltd. v. W. Bromwich Bldg. Soc'y, [1998] I All E.R. 98, 116 (H.L. 1997) (U.K.) (Lord Hoffmann) (finding Legatt L.J.'s use of these words in the Court of Appeal hearing of the case, [1998] 1 B.C.L.C. 493, "not ... very helpful").

7. See David Campbell \& Hugh Collins, Discovering the Implicit Dimensions of Contracts, in Implicit Dimensions of Contract 25 (David Campbell et al. eds., 2003).

8. Johan Steyn, Contract Law: Fulfilling the Reasonable Expectations of Honest Men, 113 L.Q. Rev. 433, 433-34 (1997). 
leave nearly enough room for choice. In this paper, I will argue against this erosion of the individual dimension of contract and particularly against the claim that it is endorsed by the relational theory of contract, which I will distinguish from the welfarist law.

I will briefly set out my argument in respect of the private law of contract in the next section of this paper, but I have had my say on welfarist developments in the private law on a number of previous occasions, and in this paper I want mainly to focus on the enormous growth of contract in the public sector over the last twenty years as part of the development of the "new public management." In the United Kingdom, the most penetrating assessment of the significance of this growth for the law of contract, its theory and its use, is Peter Vincent-Jones's The New Public Contracting, ${ }^{9}$ the thrust of which has been the basis of Vincent-Jones's presentation at the symposium entitled Governing Contracts-Public and Private Perspectives. In this paper I want to extend my views on the welfarist private law of contract to the welfarism of public sector contracting by means of a comment on Vincent-Jones's excellent account of the contractualization of the public sector.

\section{The Rise and Fall of Welfarist Contract}

It is, of course, possible, if one disagrees with the allocation of goods produced by the free market legally institutionalized in the classical law, simply to set against the classical law a welfarist law that passes disapproving social judgments on market allocations, and thereby sanctions widespread intervention in that market. It was the attractiveness of doing just this which predominantly drove those piecemeal, principally legislative, interventions in the law of contract widely understood (i.e., consumer law, landlord and tenant) which were part of the postwar construction of the general welfare state. In the immediate post-war period in the United Kingdom, the extremely challenging consolidation of this enormous amount of welfarist intervention into an overall coherent welfarist law of contract was begun in Wolfgang Friedman's Law and Social Change in Contemporary Britain of $1951,{ }^{10}$ and in Patrick Atiyah's An Introduction to the Law of Con-

9. Peter Vincent-Jones, The New Public Contracting: Regulation, Responsiveness, ReLATIONALITY (2006).

10. W. Friedmann, Law and Social Change in Contemporary Britain 34-72 (1951). For further critique of Friedmann's welfarist theory, see David Campbell, Reflexivity and Welfarism in the Modern Law of Contract, 20 Oxford J. Legal STud. 477 (2000). 
tract of 1961." To the extent that it has ever been given a properly consolidated statement, the welfarist law of contract was given that statement in the United Kingdom in the 1980s, when, in the early terms of its two major British proponents, Roger Brownsword and Hugh Collins, the welfarist law asserted its "consumer-welfarist" values over the "market-individualist" values of the classical law, ${ }^{12}$ and it was argued that the modern law of contract could be understood only if one recognized the central role in it of the "communitarian values... which gave birth to the Welfare State"13 “ . . o of paternalism, fairness and co-operation." "14 The central feature of the welfarist law, to which I am trying to draw attention, is that it is based on a clash of ultimate values; or, as Brownsword tellingly put it, of "ideologies," with paternalism in pursuit of egalitarian redistribution being preferred to the contractual justice of allocation by desert.

In my opinion, welfarist law so understood began to run out of power almost immediately after being given its best consolidated statements in the first editions of Collins's The Law of Contract of 1986 and Adams and Brownsword's Understanding Contract Law of 1987. As Atiyah, whose own views have changed markedly, has told us, this was one part of the general crisis of the British welfare state. ${ }^{15}$ Following the success of the neo-liberal attack on the welfare state, it did not seem plausible to continue to press an assault on freedom of contract that was explicitly directed at egalitarian redistributive goals (as a corollary to planning in pursuit of those goals). The loss of faith in the efficiency of central planning and command and control regulation, and in the moral value of what Nozick has called "patterning" imposed by the state, ${ }^{16}$ has been too successful for this.

The welfarist law has not failed to respond to the success of neo-liberalism, and this paper is written mainly to deal with its response in the public sector. I shall, very unfairly, basically ignore the refinements that have been made to the welfarist private law to deal with the success of neo-liberalism. Brownsword has

11. P.S. Atiyah, An Introduction to the Law of Contract 34-36 (5th ed. 1995). I have described the development of the welfarist law in David Campbell, Socio-Legal Analysis of Contract, in Socio-Legal Studies 239, 244 (Philip A. Thomas ed., 1997).

12. John N. Adams \& Roger Brownsword, Understanding Contract Law 185-206 (4th ed. 2004); John N. Adams \& Roger Brownsword, The Ideologies of Contract, 7 Legal Stud. 205 (1987).

13. Hugh Collins, The Law of Contract 1, 15 (1986).

14. Id. For more on paternalism, fairness, and co-operation, see id. at 115-77.

15. P.S. Atiyah, Freedom of Contract and the New Right, in Essays on Contract 355 (rev. ed. 1990). For commentary on the position in the United States, see Jay M. Feinman, UN-Making Law: The Conservative Campaign to Roll Back the Common Law 78-189 (2004).

16. Robert Nozick, Anarchy, State and Utopia 155-60 (1974). 
refined his welfarist position in ways that make his views a sophisticated compromise between market-individualism and welfarism, ${ }^{17}$ but these refinements seem to me to turn on equivocation over the basic character of the law Brownsword now advocates. Collins continues to claim that "welfarist regulation increasingly provides the basic discourse of the legal regulation of contracts," theory of contract can no longer comfortably be described as welfarist, for his theory tries to give private regulation, even in the interest of competition, the major role in his later view of contract.

The welfarist law of contract was particularly susceptible to this loss of faith in planned egalitarianism, for it is, in the end, a law of contract. Unless the idea of such a law is to be given a completely different meaning than it has hitherto possessed in modern society, ${ }^{19}$ a law of contract is committed to autonomy expressed in the market as freedom of choice, and, analytically, such choice is free only if one has to abide with choices one regrets as well as those one is pleased one has made. The principle of justice appropriate to allocation of goods by the market, the principle of desert, requires the enforcement of the downside of freedom of contract, and the law of contract, of course, recognizes this in the doctrine of sanctity. ${ }^{20}$ But though there can be no contractual justice without respect for sanctity, the welfarist law has been so motivated by abhorrence of the consequences of such respect as to argue for departure after departure from sanctity, ${ }^{21}$ to the point where welfarism now stands as a sort of accumulation of excuses. But, as it now has to work against the success of neo-liberalism, the welfarist law of excuse is itself in a state of acute tension, which undermines that law's ability to guide regulatory choices.

17. Roger Brownsword, Static and Dynamic Market Individualism, in Exploring THE BoundarIEs of Contract 48 (Roger Halson ed., 1996); Roger Brownsword, Contract Law, Co-operation, and Good Faith: The Movement from Static to Dynamic Market-Individualism, in Contracts, Cooperation, and Competition: Studies in Economics, Management, and Law 255, 272-79 (Simon Deakin \& Jonathan Michie eds., 1997).

18. Hugh Collins, Regulating Contracts 8 (1999).

19. Or unless, unable to accept the downside of contractual justice, we are to so equivocate about the meaning of contract as to rob the law of any determinate content. This, in my opinion, is just what happens in much of Gillian Hadfield's feminist attempt to reconcile contract with an avoidance of the necessity of visiting the consequences of agreements parties come to regret upon those parties. David Campbell, Afterword: Feminism, Liberalism and Utopianism in the Analysis of Contracting, in Feminist Perspectives on Contract Law 161, 165-70 (Linda Mulcahy \& Sally Wheeler eds., 2005).

20. See David Hughes Parry, The Sanctity of Contracts in English Law 1-18 (1959).

21. See J.H. Baker, From Sanctity of Contract to Reasonable Expectation?, in 32 Current Legal Problems 17, 22-27 (1979); Hugh Collins, The Sanctimony of Contract, in Law, Societr and Econому 63, 67, 79-84 (Richard Rawlings ed., 1997). 
This becomes all too evident when the doctrines that are to carry welfarist intervention into the general law of contract simply become too convoluted to furnish clear or effective law.

In the important, symptomatic Royal Bank of Scotland v. Etridge (No. 2), ${ }^{22}$ the foreclosure of a mortgage on a domestic home that had been pledged as security for an unpaid loan to a husband' $\mathrm{s}^{23}$ businesses was challenged on the ground that the (joint) owner wife had acted under the undue influence of (leaving aside the lender) her husband when agreeing to the security. Though I have but little respect for the classical doctrine of agreement, I read the duress, undue influence, and inequality of bargaining power cases such as Etridge, in which that doctrine is criticized on welfarist grounds, with dread, for they lack any coherent principle and, in the face of their incoherence, merely add a bewildering pleonasm to express that incoherence. ${ }^{24}$ The practice that gave rise to Etridge itself, the pledging of domestic homes as security for business credit, lies behind a number of small and medium business success stories, and really there is nothing more, at root, to say than that such success entails running the risk of losing the homes. When the risk crystallizes, the loss of the home is regrettable, especially if dependent children are involved. This is, perfectly understandably, unacceptable to the welfarist cast of mind, and it is arguable that pledging homes (especially if dependent children are involved) should be prevented by legislation. (Subject to solving some tricky issues about devising an adequate rule, this is my own position when children are involved.) But now, in the wake of the success of neo-liberalism, intervention of this sort is also not readily acceptable to the welfarist cast of mind, for it is clear that this use of domestic homes does, in fact, typically reflect the free choices of parties, and its prevention would be opposed, not merely by putative creditors, but by putative sureties. When the pledge gets what proves to be a successful small business off the ground, the views of the surety are rather different from those professed ex post in Etridge. The result, in an era in which the appeal courts are not loathe to engage in judicial legislation, is that Etridge creates an

22. Royal Bank of Scot. plc v. Etridge (No 2), (2002) 2 A.C. 773 (H.L.) (appeal taken from Scot.) (U.K.).

23. By no means have all these problematic mortgages involved marital or cohabitation relationships; some have involved, for example, mothers and children. See, e.g., Megan Richardson, Protecting Women Who Provide Security for a Husband's, Partner's or Child's Debts. The Value and Limits of an Economic Perspective, 16 Legai. Stud. 368, 368 (1996).

24. See David Campbell, The Relational Constitution of the Discrete Contract, in Contract and Economic Organisation: Socio-Legal Initiatives 40, 40-45 (David Campbell \& Peter VincentJones eds., 1996). 
absurd set of notice requirements that do not speak to the issue, would not resolve the irresolvable issue if they did speak to it, and that inevitably are creating their own problems, largely because they vacillate so much that one cannot understand their point.

The recognition that welfarist vitiating factors such as economic duress, unconscionability, and inequality of bargaining power make unsatisfactory law is by no means novel, but, in my opinion, the very point of Etridge is that it proceeds regardless, putting forward changes that are as senseless as if they were positive reforms. There is change in the detail of the law but no progress in the refinement of the law as regulation; quite the opposite is true, in fact. The manifest unsatisfactoriness of Etridge as practical law illustrates the paralysis of the welfarist law as a guide to regulation through private law.

\section{Welfarism and the New Public Contracting}

Ultimately based on Milton Friedman's criticism of Keynesian macro-economic management and on Ronald Coase's criticism of the Pigouvian case for piecemeal intervention, the principal aim of neo-liberalism initially was to reduce the extent of state intervention in the economy. The theoretical debate and social and political conflict initially provoked by neo-liberalism focused on the "retreat of the state. ${ }^{25}$ It is unarguable that general fiscal management, direct public ownership, command and control regulation, and certain important forms of welfare provision have been reined back or even abandoned. But it is now, in my opinion, so obvious as no longer to need arguing, that the state has not retreated at all. ${ }^{26}$ The form of state intervention has been changed, with the concept of contract being at the heart of the change. The "new public management" seeks to marshall an economic efficiency it identifies with the conduct of private sector business to public purposes by basing public sector activity on contracts. The retreat of the state actually has been a process of the maintenance or even the expansion of the public sector. This expansion has taken place under the guise of contract, so that now the larger part of public expenditure is described as being quasi-contrac-

25. See, e.g., Susan Strange, The Retreat of the State: The Diffusion of Power in the WORLD ECONOMY (1996).

26. For an excellent summary of the argument, see Peer Zumbansen, Vertragsregimes im "Dritten Sektor," in Bucerius Law School, Non Profit Law Yearbook 2002 61, 83-84 (Hein Kötz et al. eds., 2002). It is a brief statement of what I would wish to say myself on this issue. 
tual or hybrid. Obfuscation about the size, extent, and nature of public intervention is at the heart of the "third way" followed by contemporary government.

Leaving aside the way in which the description of private finance initiatives as "private" is a direct tool of fiscal policy, serving the macroeconomic purpose of keeping much public sector capital investment off balance sheet, we can say that the main function of the new public management has been to respond to the success of neo-liberalism by giving public expenditures some of the color of the efficiency and voluntariness that are associated with private contracts and the market. In an influential early account of the developments in the United Kingdom, Ian Harden claimed that the new public management was creating "the contracting state," by which he meant a state that shrinks in size, in major part by transferring formerly hierarchically-organized functions to contract. ${ }^{27}$ What we now see as the major error of this ingenious pun is the claim that the state shrinks. But it is also the case, as we shall now see, that there are errors involved in claiming that the contracting state makes contracts.

Peter Vincent-Jones has produced the most penetrative commentary on what it now means to describe new public management as a process of contractualization. His is the leading British work of what might be described as the second phase of analysis of the new public management, written in light of the growth, not the retreat, of the contracting state. Using a concept of contracting derived from an unusually thorough understanding of the work of Ian Macneil, VincentJones evaluates how far the forms of public sector contract adhere to the appropriate norms of welfare-enhancing contracting that are the foundations of Macneil's relational theory of contract. Vincent-Jones's awareness of generally unknown or disregarded aspects of Macneil's thought, and particularly of Macneil's "relational theory of exchange" (not only of "contract"), makes his articulation of a relational theory of hybrid governance particularly strong. Nevertheless, passing straight over the rich empirical detail of Vincent-Jones's evaluations of these forms of contracting to my own evaluation of the new public management, I must say that I find the picture he paints to be very worrying.

Vincent-Jones distinguishes three broad forms of public sector contracting:

(1) [A]dministrative contracts regulate relationships between parts of government; (2) economic contracts promote outsourcing in central and local government and serve in the quasi-market restruc-

27. See Ian Harden, The Contracting State 70-71 (Studies in Law and Politics Series No. 5 , Norman Lewis \& Cosmo Graham eds., 1992). 
turing of entire welfare sectors and in the procurement of public infrastructure such as schools and hospitals; and (3) social control contracts operate as instruments of behavioral modification in the regulation of relationships between state agencies and deviant or "problem" citizens. ${ }^{28}$

An important distinction must, I think, be drawn between administrative contracts and the other two forms of contract. Administrative contracts can properly be analyzed as a contractualization of what continues to be acknowledged to be hierarchical ordering. (Vincent-Jones's sophisticated discussion of the proper roles of the legal, administrative, and political "remedies" available to enforce administrative contracts makes this particularly clear. ${ }^{29}$ ) This part of Vincent-Jones's work invites comparison to Williamson's analysis of the M-form firm structure. ${ }^{30}$ The attempt to create internal markets and hence competitive pressure within public sector hierarchies is a public sector equivalent to the private sector attempt to create a similar pressure through the creation of semiautonomous divisions of a firm. VincentJones's administrative contracts are, then, very important economic institutions of the contemporary capitalist economies, but they should, I think, be properly regarded as self-conscious forms of hierarchy; indeed, an acknowledged major pathology attending the introduction of administrative contracts has been the incentive given to parties to maximize competition from the perspective only of the contractualized unit, rather than from the perspective of that unit within the hierarchy.

By contrast, economic and social control contracts are characterized by an absence of agreement and an absence of sanctity. Maintaining that they are contracts nevertheless involves serious obfuscation about their hierarchical nature, as opposed to their claimed decentralized nature. Not being subject to the control of penal authorities myself, I am able to laugh at the idea of, for example, those on probation entering into good behavior "contracts" with such authorities. But, in my opinion, this is merely a grotesque exaggeration of the misuse of the concept of contract, and especially of the connotation of voluntariness in agreement, which characterizes the new social control contracts. Arguably, the main misuse of the concept of contract in economic contracts is the implication that these contracts create incentives for ef-

28. Peter Vincent-Jones, The New Public Contracting: Public Versus Private Ordering?, 14 Ind. J. Global Legal Stud. 259, 261 (2007) (emphasis added). This excerpt summarizes the classification in Vincent-Jones, supra note 9, at 21-25.

29. See Vincent-Jones, supra note 9, at 11-14.

30. Oliver E. Williamson, Markets and Hierarchies: Analysis and Antitrust ImplicaTIONS 132-54 (1975). 
ficiency by normally imposing financial parameters that are binding, which plays on the connotations of sanctity in private contract. I flatter myself that I have played some role in making it clear why flexibility must play a crucial role in major private projects, and Vincent-Jones makes generous reference to a paper Donald Harris and I wrote on this subject. ${ }^{31}$ But, ungratefully ignoring the ways in which VincentJones is right, I would say that the sort of flexibility I have tried to identify in private projects should be distinguished from what seems, on the evidence of particularly the private finance initiative, to be the typical pricing behavior displayed in economic contracts. In these economic contracts, commitment to the project is won by initially underestimating the cost, in the confident belief that, once the initial commitment is made, further public funds will be made available to avoid the cancellation of the heralded project, even if, or when, it incurs even spectacular overruns.

It is important that the reader make direct reference to The New Public Contracting itself, not only because I am doing no justice whatsoever to the rich detail of Vincent-Jones's account, but because he himself, though critical of the many specific failures that he identifies of the new public management to give substance to welfare-enhancing contractualization, does not draw nearly so pessimistic a conclusion from the material as do I. Despite The New Public Contracting having, as he claims, "highlighted the glaring disparity between the social contract rhetoric adopted by New Labour and the reality of the New Public Contracting," 32 Vincent-Jones still holds out the possibility of devising welfare-enhancing governance structures that transcend the public-private divide by being quasi-contractual hybrids between hierarchy and market. In his latest formulation, set out in his paper elsewhere in this issue, the necessarily reformed "proceduralization" of contractualization is described as democratic experimentalism, a development of the now very extensive literature on deliberative democracy. ${ }^{33}$

I will not go into the detail of what Vincent-Jones requires of an adequate process of the design of hybrid contracts, for I believe his underlying belief in the retrievability of economic and social control contracts is mistaken at a fundamental level. After the success of the neo-liberal critique of command and control and of patterning, it was impossible to continue to advocate welfarism on the basis of the extension of these techniques, and, indeed, if welfarism was completely iden-

31. David Campbell \& Donald Harris, Flexibility in Long-term Contractual Relationships: The Role of Co-operation, 20 J.L. Soc'y 166 (1993), reprinted in The Economics of Public-Private Partnerships 170, 170-95 (Darrin Grimsey \& Mervyn K. Lewis eds., 2005)

32. VinCENT-JONES, supra note 9 , at 359.

33. Vincent-Jones, supra note 28 , at 275-76. 
tified with these techniques, it would have been a casualty of the neo-liberal critique along with them. The public sector as such would have had to shrink and the market sector to grow. But the new public management breaks the identification of welfarism with command and control and with patterning, allowing the public sector to remain steady and even grow. Instead of command and control, we have, after the fundamental "reconceiving" 34 of the nature of the "[re-]regulatory state" 35 during the "age of regulatory reform," 36 an immense growth of soft law, some of the central public sector institutions of which are the economic and social control contracts described by Vincent-Jones.

Faced with the failure of command and control, the central claim made for soft law is that it is more effective, principally because it is more "reflexive' ${ }^{\text {'37 }}$ or "responsive,"38 and, though they cannot be directly traced to Macneil, these are the main criteria by which Vincent-Jones assesses contractualization in The New Public Contracting. And, while he is properly critical of the many failures in this area, rejecting some forms of new public contract that do not "meet the threshold conditions of contractual relations, ${ }^{39}$ Vincent-Jones does hold out hope for a reformed contractualization in which the reflexivity and responsiveness will now follow from the reformed, democratic experimentalist proceduralization of the design of the forms of hybrid contract. The full reply to these claims that Vincent-Jones deserves would require an assessment of all the hybrid forms he sets out, which itself would have to be put alongside an evaluation of the soft law regulation of the private sector. I will, however, comment on only two issues which The New Public Contracting shows to be central to an evaluation of the process of contractualization in the United Kingdom.

From his earliest work, Peter Vincent-Jones has shown an extraordinary felicity with that aspect of sociological analysis that Weber regarded as so enormously important: the construction of classifications. ${ }^{40}$ The New Public Contracting

34. See generally Cass R. Sunstein, After the Rights Revolution: Reconceiving the ReguLatory State (1990).

35. See generally Giandomenico Majone, The Rise of the Regulatory State in Europe, 17 W. Eur. PoL. 77 (1994).

36. See generally The Age of Regulatory Reform (Kenneth Button \& Dennis Swann eds., 1989).

37. Gunther Teubner, Law as an Autopoietic System 97 (Anna Bankowska \& Ruth Adler trans., Zenon Bankowski ed., 1993).

38. Inn Ayres \& John Braithwaite, Responsive Regulation: Transcending the Deregulation Debate 158 (1992).

39. Vincent-Jones, supra note 9, at 355.

40. Peter Vincent-Jones, Contract and Business Transactions: A Socio-Legal Analysis, 16 J.L. Soc'y $166(1989)$. 
is the culmination of research sustained for more than a decade during which Vincent-Jones has managed to place the various forms of public sector contract into a comprehensive and coherent classificatory scheme (administrative, economic, and social control contracts form only the first level of classification) that undoubtedly is the best place to start when one wishes to see the detail of what has happened over the course of the process of contractualization.

However, the very coherence Vincent-Jones brings to what has happened is, in my opinion, misleading in an important way. The U.K. government has not had any overall grasp on what it has been doing, other than at the most very general level; even there, we have seen that the perception is one of shrinking the state, which has been quite mistaken. I am not trying to drive at the way that, as Vincent-Jones says throughour his book, the process of contractualization hitherto has been characterized by a lack of democratic accountability, ${ }^{41}$ but at the more prosaic point that contractualization has involved a chaotic plethora of initiatives that it is really quite wrong to say amounts to a coherent program at all, and certainly not to a program of experimentation. A process of experimentation is indeed a process of trial and error, but the scientist who stumbles from one failure to another and, at the end of, say, a quarter century, says frankly that the basic issues still have to be addressed, is not a good scientist, but rather one who has called into question the wisdom of persistence with his research program.

If one tries to grasp the atmosphere of contractualization so far, one should turn to the journalist Simon Jenkins's Thatcher and Sons ${ }^{42}$ Although it is hardly to be compared to The New Public Contracting as a work of analysis of the forms of new public contract, it does capture the nature of the process of contractualization: an authoritarian growth of the central state which has sanctioned all sorts of absurdly inefficient or outright wasteful projects. Vincent-Jones is perfectly well aware of all of this, but believes that it is remediable if only intervention were properly formulated. I myself see nothing in the evidence he and others bring to our attention to make me believe that the irrational process of contractualization will now become fundamentally rational. Rather than look to an improved process such as refined democratic experimentalism, my own opinion is that, speaking generally, it is now incumbent upon us to really bring about the retreat of the state. This is the point of real disagreement I have with Vincent-Jones.

It is worth asking why Vincent-Jones and I should reach differing conclusions about the basic rationality or irrationality of a process I am sure he describes excel-

41. See generally Vincent-Jones, supra note 9.

42. Simon Jenkins, Thatcher and Sons: A Revolution in Three Acts (2006). 
lently, and this brings up the issue of the voluntariness of the new public contracting. If one believes that the purpose of state intervention is to bring about desired results, then one judges intervention by its effectiveness in bringing about those results. With this attitude, contracts that cannot plausibly be said to be the product of anything other than the most formal and actually insubstantial agreement of the non-state party have to appear plausible. ${ }^{43}$ Indeed, they are merely one of the tools that are the common currency of contemporary governmental technique. When outright command is deemed to be ineffective in the light of the critique of command and control, then advertising commissioned by public authorities that uses all the manipulative techniques of the corporate sales effort, "stealth" taxes normally incomprehensible to those subject to them, and soft law regulations of low "visibility" are all possible. One is struck by the way that techniques rightly deplored when used by the private sector in its relationships with consumers seem to undergo a moral whitewash when they are used by the public sector in its relationships with citizens. But, of course, the end is justifying the means, and it is the abiding mark of welfarism in the analysis of new public contracting that, the end being public rather than private, it tends to be accepted as good.

Of course, leaving aside the general issue of the questionable reality of the democratic mandate of the European Union and of U.K. central and local governments, and merely focusing on what passes for the process of setting the public goals of contractualization, ${ }^{44}$ one might well question this process, as VincentJones certainly does on numerous occasions. I could not put the point I am trying to make better than he does when he says that " $[\mathrm{t}]$ he legitimacy of the exercise of regulatory power is dependent on the reasons for desired behaviour being made explicit both to regulatees and to wider society. ${ }^{245}$ Nevertheless, I hesitantly suggest that Vincent-Jones does not take this seriously enough. His book furnishes enough material to damn the improper use of "contract rhetoric."'66 But VincentJones ultimately is happy that the contract in contractualism is a technique of intervention that tries to produce predetermined results - in essence, a pattern. This is the theoretical core of his book:

The distinguishing feature of the New Public Contracting is the deployment of administrative contracts, economic contracts, and

43. Vincent-Jones, supra note 9 , at 262-63.

44. See id. at $266-68$.

45. Id. at 119.

46. See id. at 9-11. 
social control contracts for the attainment of particular policy purposes. [The book's] concern is solely with purposive contractual mechanisms through which relations are ordered within government, or in economic organization, or between the state and individual citizens. ${ }^{47}$

In essence, Vincent-Jones believes it is right, in principle, that public purposes be pursued by new public contracts, though these should be reformed so as not to remain contracts merely in rhetoric. His basic aim, representing the dominant welfarist thinking on this topic, is to expand the realm of contract beyond the private sector, ${ }^{48}$ and was expressed in a draft of the paper he gave at the Governing Contracts symposium:

The traditional response of lawyers [to the rise of the new public management] has been to argue that public law controls should be extended to redress the resulting decline in public law accountability ... By contrast, radical legal scholars throughout the common law world, rejecting the rigid dichotomy of public and private law on which such prescriptions are based, have argued in favour of the development of new models of administrative law. ${ }^{49}$

But, as I have argued on a previous occasion, I do not believe the concept of a contract that is a hybrid between public and private, or hierarchy and market, though obviously it is at the core of the process Vincent-Jones describes and of his thinking about it, is sustainable. ${ }^{50}$ The point about private allocation via the market is, precisely, that it is private. It is directed at the satisfaction of goals set by private parties because the moral foundation of liberal democratic society is respect for the autonomy of its citizens, which, in respect of economic goods, may be prosaically expressed as the belief that they know their own interests best. Liberal democratic society's best claim to legitimacy rests not on the moral value of particular social goals set by that society, but on the extent of the freedom of its citi-

47. Id. at 34 .

48. Id. at 35.

49. Peter Vincent-Jones, The New Public Contracting: Public Versus Private Ordering? 17 n.5 (Feb. 17, 2007) (Unpublished manuscript on file with the Indiana Journal of Global Legal Studies).

50. David Campbell, The "Hybrid Contract" and the Merging of the Public and Private Law of the Allocation of Economic Goods, in Promoting Participation: Law or Politics? 45 (N. Douglas Lewis \& David Campbell eds., 1999). 
zens to set their own goals. One may say that the goal of liberal democratic society should be to eschew the pursuit of social goals. In particular, the claim that the market economy is efficient is not a claim that that economy efficiently produces a particular set of morally valued goods, but is a claim that goods are allocated through the voluntary choices of economic actors. The legitimate use of contract requires the creation of, as Walzer put it, a "market as a sphere," in which the public authority which frames that sphere does not attempt to produce results within it, but leaves the results to the outcome of the voluntary contractual commitments of the parties."

I have said enough to make it plain that I do not think economic and social control contracts can ever be legitimate. This does not mean that the state might not legitimately intervene in areas in which intervention now takes the form of economic and social control contracts, though I should make it plain that I do not think it should do remotely as much as it now tries to do. But the state cannot legitimately intervene by means of the hybrid contract, for the central feature of that contract is that it obfuscates the hierarchical coercion that is the identifying feature of state intervention, and it is wrong that the state should intervene in this way. When the state intervenes, it should intervene for an agreed public purpose. It cannot eschew the setting of public goals. But the whole point of a market is that it makes individual choice possible by coordinating in the absence of such goals. While I should be the last to deny the importance of the development of reflexivity in the determination and pursuit of social goals, legitimate intervention by the state requires the visibility of the operation of its regulatory mechanisms. But such visibility, by encouraging noncompliance, was a significant problem associated with command and control. In my opinion, the conclusion one should draw from this is that, faced with an ineradicable lack of effectiveness in visible regulation, we should not subtly disguise the intervention by contractualizing it, but instead should withdraw the intervention, and so typically enlarge the private sphere. In a phrase, we should far more often seek to make actual the real retreat of the state.

\section{Excursus on the Philosophy of Welfarism}

Though Vincent-Jones makes no reference to it, nor was required to do so, I think his work should be set against the basic shift that has occurred in welfarist

51. Michael Walzer, Spheres of Justice: A Defense of Pluralism and Equality 119 (1983). 
political philosophy over the period that has seen the development of the new public contracting. Itself reeling from the success of neo-liberalism, welfarist political philosophy abandoned the direct pursuit of egalitarianism, perforce accepting at least part of the efficiency argument that thoroughgoing egalitarianism involved too much sacrifice of rational economic incentives, and also accepting perhaps a greater part of the moral critique of patterning. Equality of opportunity has replaced equality of outcome as the basic goal of welfarism. This is distinguished from the equality of opportunity long identified with the principle of desert by the transparent trick of seeking to establish an equality of resources such that equality of opportunity leads to equality of outcome. A brief look at the sort of resources which it is sought to equalize, which in Dworkin's case includes talents and handicaps (which are at most a small step away from luck), ${ }^{52}$ tells us that the acceptance of distribution by desert in these philosophies is of only the most grudging sort. Really they are an attempt to bring about, by a back-door route, the egalitarianism they have had to acknowledge is unacceptable. These philosophies are, therefore, illegitimate in their own terms, and, to me, unappealing. Though these philosophies can be traced to John Rawls, they display a most important difference from him. Just as the U.K. welfare state has been unable to keep itself within the minimalist bounds of Beveridge's goal of the "abolition of want," ${ }^{33}$ and is now threatened by the unacceptability of its maximalist expansion far beyond the concept of a social security floor, so equally these philosophies have been unable to confine their ambition to the distribution of primary goods envisaged by Rawls, ${ }^{54}$ and are similarly maximalist themselves.

The complication arises, of course, that pursuit of egalitarianism by indirect means will likely magnify the practical difficulties of that pursuit. While this hardly matters in economic theory or abstract political philosophy, and indeed adds to the fun of discussions of complex equality, it makes it impossible, as F.A. Hayek warned us long ago, ${ }^{55}$ to base an effective and legitimate policy on these political philosophies. ${ }^{56}$ Of all the criticisms made of Dworkin, the one I find most

52. Ronald Dworkin, Sovereign Virtue: The Theory and Practice of Equality 77-82, $85-92(2000)$.

53. William Beveridge, Social Insurance and Allied Services 7 (Am. ed., Macmillan Co. 1942).

54. John Rawls, A Theory of Justice 347-50 (rev. ed. 1999).

55. See 2 F.A. Hayek, Law, Legislation and Liberty: the Mirage of Social Justice 62-100 (1976).

56. In The New Public Contracting, supra note 9, and in his paper given at this Conference, supra note 28 , Vincent-Jones draws our attention to the following highly perceptive comment of 
telling is that of Ely. Dworkin's early view of adjudication clearly required the "fusion of constitutional law and moral theory," which "incredibly, has yet to take place."' Wr Writing in 1972, Dworkin did have the bravery to recommend "an abstract and complex book about justice"s8 recently published by Professor Rawls of Harvard to constitutional lawyers as a guide to their practice. Ely memorably asked:
Rawls's book is fine. But how are judges to react to Dworkin's invi- tation when almost all the commentators on Rawls's work have ex- pressed reservations about his conclusions? The Constitution may follow the flag, but is it really supposed to keep up with The New York Review of Books?59

The feeling I had that Dworkin's right answer position was so impracticable as to make it obvious that it could not be a guide to real world adjudication, now also strikes me as applicable to his political philosophy. Even when stated in terms which emphasize the importance of "the practice of equality, ${ }^{\text {"60 }}$ that emphasis itself is merely theoretical, and Dworkin's views remain so impracticable that one cannot see how to base an effective economic and social policy on them. Abandoning direct income redistribution, Dworkin even goes so far as to propose insurance markets that will provide income streams which fully compensate for the unequal rewards that follow from differing endowments of talent. The difficulty is not that one fears that this proposal involves uninsurable risks and impossibly expensive liabilities based on the "policies" of precisely those who pose the greatest risk of default. It is that the rococo elaboration of the proposal, which disguises its basic egalitarian thrust, makes it impossible to see what is being proposed. These are "markets" that are to be brought into existence where real markets emphati-

Salamon on the "tools" of contemporary government: "The more complex and convoluted the tool, the more separate actors are involved, the more difficult it is likely to be to manage. Some tools are more cumbersome to operate than others. While they may promise great efficiency and effectiveness in theory, they are unlikely to deliver it in practice because of the managerial difficulties they pose." Lester M. Salamon, The New Governance and the Tools of Public Action: An Introduction, in The Tools of Government: A Guide to the New Governance 1, 24 (Lester M. Salamon ed., 2002).

57. Ronald Dworkin, Taking Rights Seriously 149 (1977).

58. Id.

59. John Hart Ely, Democracy and Distrust: A Theory of Judicial Review 58 (1980).

60. Ronald Dworkin, Sovereign Virtue: The Theory and Practice of Equality pt. II (2000). 
cally would not exist, and what is meant by a "market" of this sort? It is to the immense credit of Vincent-Jones's discussion of the new public contracting that it compels us to place contractualism in the context of the spirit of the age expressed in these leading philosophies.

\section{The Relational Theory and the Nature of Private and Public Ordering}

There must be some warrant for reading the relational theory of contract as a form of what I have called welfarism, for almost everyone has done it. This is not the place to go into the reasons why this is so, but it would be remiss of me not to mention in this context Peer Zumbansen's paper given at this Governing Contracts symposium, ${ }^{61}$ which excellently reviews the U.S. material contributing to the formulation of the welfarist law, including the very important pre-war contributions of Cohen and Hale. His discussion of the post-war literature is acute in focusing on Duncan Kennedy rather than Stewart Macaulay or Ian Macneil, as I believe Kennedy has had the greatest influence on forming the general opinion of the relational theory of contract, and particularly on the conflation of it with the welfarist theory. Zumbansen emphasizes the importance of Kennedy's 1976 paper entitled "Form and Substance in Private Law Adjudication," has, I suspect, been the most influential gloss on the work of Macaulay. But it should be recalled that the principal work of Macaulay's on which Kennedy's paper is based deals with a particular problem of consumer law, "the duty to read," ${ }^{\prime 3}$ and while it is true that Macaulay would like to see the greater subsumption of the classical law of contract to welfarist consumer protection law, ${ }^{64}$ Kennedy's focus does not really convey Macaulay's views of the use of contract in commercial life. Nevertheless, both Kennedy's and Macaulay's views on this topic are much more nuanced than many scholars sometimes appear to believe.

Whatever may be the case regarding Kennedy's and Macaulay's positions, I

61. Peer Zumbansen, The Law of Society: Governance Through Contract, 14 Ind. J. Global LegaL Stud. 191 (2007).

62. Duncan Kennedy, Form and Substance in Private Law Adjudication, 89 Harv. L. Rev. 1685 (1976).

63. Stewart Macaulay, Private Legislation and the Duty to Read-Business Run by IBM Machine, the Law of Contracts and Credit Cards, 19 VANo. L. Rev. 1051 (1966).

64.See generally Stewart Macaulay, Bambi Meets Godzilla: Reflections on Contracts Scholarship and Teaching vs. State Unfair and Deceptive Trade Practices and Consumer Protection Statutes, 26 Hous. L. Rev. 575 (1989). 
am certain that Ian Macneil's own views on contract are not welfarist, and, indeed, his basic achievement is to preserve competition within the overall cooperative framework of the relational theory in his treatment of the "discrete" as opposed to "relational" elements of contracting. I have argued this at length elsewhere, ${ }^{65}$ and will here cite only Macneil's comments on the Critical Legal Studies movement's failure to give discreteness a place in its treatment of contract:

\begin{abstract}
The Critical Legal Studies movement ... has avoided facing up to what it means to incorporate the discreteness universally found in material relations into [the] general principles and law of such relations. They seem most often to prefer pointing out the obvious limitation of the discrete general law of contract only in terms of a limited set of relational concerns. These are mainly concerns relating to equality and participation of individuals in relations affecting their lives [but] we must have some law dealing with discreteness in contractual relations. ${ }^{60}$
\end{abstract}

The basic thrust of the relational theory as Macneil has it is to make the social foundation of contracting explicit. Self-consciousness of this social foundation obviously will rule out the atomistic individualism which Macneil believes underpins the classical law of contract (and insufficiently rethought "neoclassical" versions of this) and its corollaries in mainstream economics, both of which meet in law and economics of Posner's sort, and obviously this will involve significant reforms of the current law of contract, which gives too much scope to such individualism. But the basic reform of the law of contract Macneil envisages seeks to preserve freedom of contract within the market sphere and to reject patterning and welfarism. It is intended to be a "purely processual" reform. ${ }^{67}$ To the extent it succeeds in this, the main policy advantage I believe the relational theory has over welfarist theories of contract is that it allows us to maintain the autonomy of the

65. David Campbell, Ian Macneil and the Relational Theory of Contract, in The Relational Theory of Contract: Selected Works of Ian Macneil 3 (David Campbell ed., 2001).

66. Ian R. Macneil, Barriers to the Idea of Relational Contracts, in DeR Komplexe Langzeitvertrag/The Complex Long-term Contract 31, 37 (Fritz Nicklisch ed., 1987).

67. Rick Bigwood, Exploitative Contracts 171-225 (2003). Bigwood says much of what I would want to say about this topic, had I the ability, though Macneil plays almost no part in Bigwood's thinking. I have reviewed this book in David Campbell, Book Review: Exploitative Contracts, 64 CAMBRIDGE L.J. 243 (2005). 
market sphere while being self-conscious of the social foundation of contract and market.

Doing this requires us not only to limit public intervention in the market sphere, but to respect a boundary between the market sphere of the allocation of economic goods according to private ends, and the public sphere which, of its nature, should pattern. Of course, such patterning, and the coercion it involves, will have to be defended as such. But the very sophistication of the concept of hybridity breaks down the boundary between private and public, and, indefensibly in my view, obfuscates the nature of the public ordering. The result is tantamount to a mirror image of the obfuscation of the nature of private ordering that all leftwing contract theories have sought to clear away. At the cost of repeating myself, let me stress that, after the success of the neo-classical critique of command and control and of patterning, it was only by obscuring the nature of the public sphere with a contractual cloak that it has been possible to maintain or even expand the scale and scope of state intervention.

\section{Conclusion}

I will have failed to express myself properly if this response to Peter VincentJones's outstanding account of the new public contracting is read as criticism in any fundamentally negative sense. I agree with Vincent-Jones's account, and, indeed, I have learned the majority of what I know of the new public contracting through reflection on his work, and on the other work to which he has drawn my attention. ${ }^{68}$ What $I$ do intend is to express a different evaluation of the process Vincent-Jones describes. Vincent-Jones makes many balanced but telling criticisms of this process, but asks for a reformed process of policy formulation to make sure past failings are avoided in the future, in what is, ultimately, an approving stance. I, by contrast, want to be entirely critical of the new public contracting.

The new public contracting is the principal response that has been made to the successful neo-liberal critique of the effectiveness of command and control and the moral legitimacy of patterning. The pursuit of increased effectiveness through reflexivity, responsiveness, etc. has driven the development of all the sophisticated forms of new public contract, and, at a wider level, soft law in general.

68. I should also mention my indebtedness to Douglas Lewis, whose major contribution to the first phase of the analysis of the new public management played a similarly important role in the formation of my views on these matters some twenty years ago. 
In my opinion, this has not led to any increase in effectiveness, but rather to such a growth in the scope of intervention and in the softening of the techniques of intervention that one cannot rank, or even really identify, the social goals that we are using these techniques to pursue; of course, this makes them ineffective. A veneer of voluntariness has been given to interventions in the form of economic and social control contracts by calling them contracts, which has intrinsic connotations of agreement. But this is, in my opinion, seriously misleading, and while there no doubt are differing degrees of deceit, I regard the effort as a whole as illegitimate, for in these contracts, the pursuit of the expression of the intentions of the parties is always subordinated to the refined pursuit of a pattern. Leaving aside the objections to patterning itself, patterning of this sort, which dare not speak its name, is entirely illegitimate.

I do not see any remedy for this while the new public management covers itself in the cloak of contractualization. I believe I still speak as a socialist who has repeatedly argued for direct state provision of some goods, and the necessity of state involvement in establishing the institutions for the provision of all goods, when I say that contractualization is a grave mistake, that efficiency and moral legitimacy require intervention to be frank about its coercive, rather than voluntary, basis, and that the public sector be shrunk. But, at a time when left-wing politics are dominated by attempts to seize state power in order to impose what are believed to be welfare-enhancing policies on others who do not share those beliefs, ${ }^{69} \mathrm{I}$ am conscious that my views are anachronistic. Perhaps I should conclude by making it clear that what I have said here rests on my belief that socialism's only possible justification is, as Orwell put it, that it is necessary to "preserve and even enlarge the atmosphere of liberalism. ${ }^{\text {"7o }}$

69. See David Campbell, Bringing Law and Lawyers to the People: Statism and Anarchy in Leftwing Legal Thought, 11 Soc. \& Lecal Stud. 413, 421 (2002).

70. George Orwell, Inside the Whale, in Inside the Whale and Other Essays 9, 48 (1962). Orwell had earlier written: "[Socialists] have never made it sufficiently clear that the essential aims of socialism are justice and liberty." George Orwell, The Road to Wigan Pier 214 (Harvest Books 1972) (1937). 